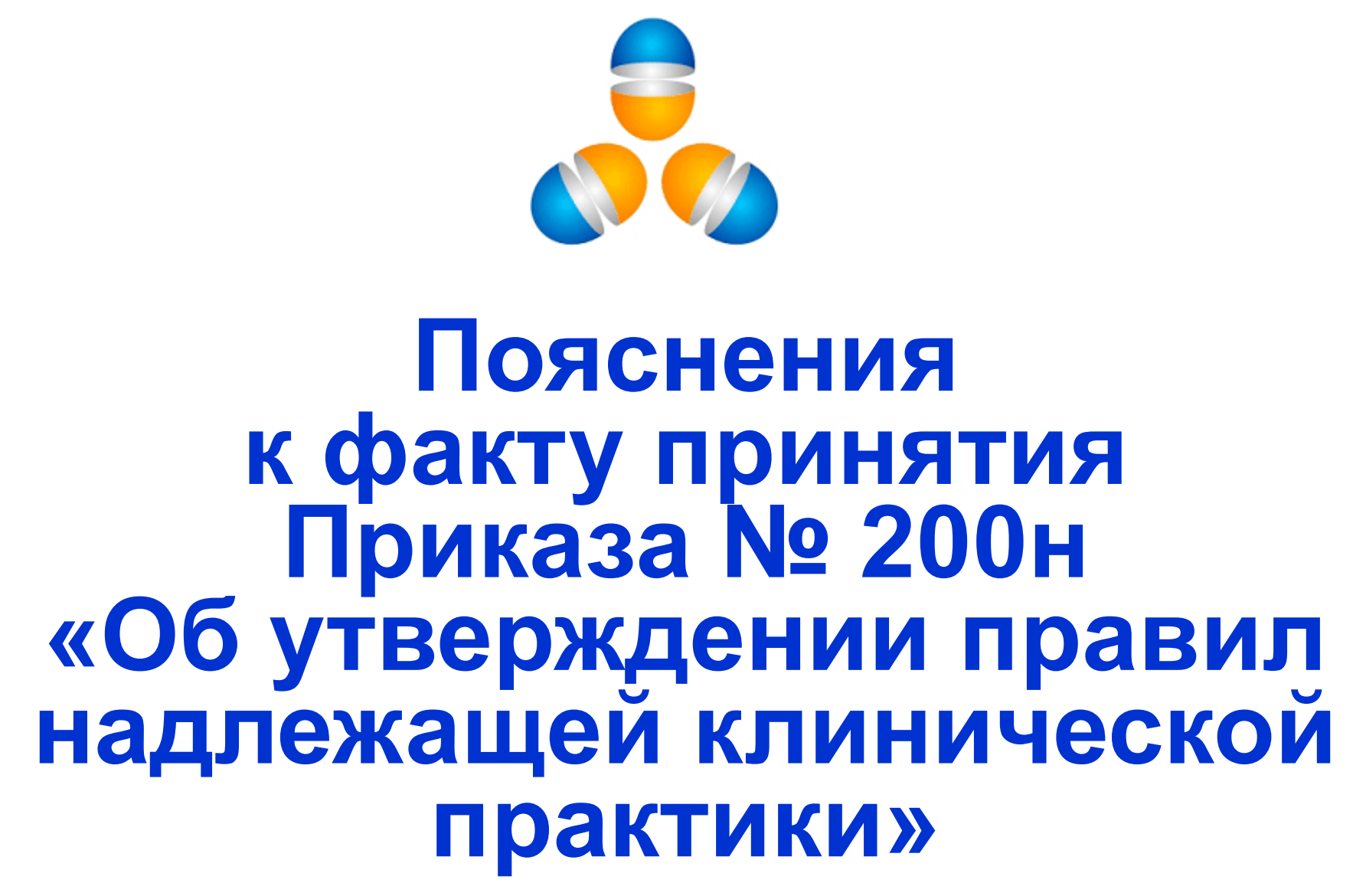




\section{Что случилось?}

1 апреля 2016 г. Минздравом России принят Приказ № 200н «Об утверждении правил надлежащей клинической практики».

Приказ зарегистрирован Минюстом России 23 августа 2016 г. за № 43357.

Индустрия узнала об издании Приказа лишь 24 августа, после его публикации на официальном интернет-портале правовой информации. 


\section{Когда Приказ № 200н вступает в силу?}

Поскольку срок вступления в силу в самом акте не указан, действует общее правило - Приказ № 200н вступает в силу по истечении 10 дней после дня его официального опубликования (24 августа 2016 г.), т.е. с 4 сентября 2016 г.

Однако пунктом 2 Приказа № 200н установлено, что Правила надлежащей клинической практики, утвержденные данным приказом, распространяются на правоотношения по проведению клинических исследований, заявления о выдаче разрешений на проведение которых поданы после вступления Приказа № 200н в силу (т.е. после 4 сентября 2016 г.). 
Каково место Приказа № 200н в системе законодательства, регулирующего проведение клинических исследований?

Приказ № 200н пришел на смену Приказа Минздрава России от 19.06.2003 № 266.

Согласно п. 3 вновь принятого Приказа Приказ № 266 утрачивает силу. 


\section{Какие Правила должны применяться к текущим клиническим исследованиям, заявление на проведение которых подано до 4 сентября 2016 г.?}

Учитывая, что новые Правила надлежащей клинической практики распространяются только на те исследования, заявления о выдаче разрешений на проведение которых поданы после 4 сентября 2016 г., а Приказ Минздрава от 19.06.2003 № 266 утрачивает силу с 4 сентября, то, исходя из буквы закона, ни тот, ни другой документ не применяется к текущим исследованиям, заявления на проведение которых поданы до 4 сентября 2016 г. Таким образом, говоря о специальных нормах российского права, основным документом, применяемым к данным исследованиям, является, по сути, лишь закон «Об обращении лекарственных средств».

Однако никто не отменял необходимость следовать требованиям ICH GCP при проведении международных клинических исследований. 


\section{Что из себя представляет Приказ № 200н?}

Приказ № 200н представляет собой достаточно вольное, порой существенным образом творчески переработанное изложение ICH GCP с вкраплениями норм закона «Об обращении лекарственных средств» и некоторых других российских и международных требований.

При этом авторы довольно хорошо справились с этой задачей, и упомянутая достаточно существенная творческая переработка ICH GCP не привела к катастрофической потере смысла. Есть, конечно, определенные расхождения, однако АОКИ не ожидает, что они сколь-либо существенным образом повлияют на процесс проведения международных клинических исследований в Российской Федерации. 


\section{Чmo буdem с ГОСТ P 52379-2005?}

С ГОСТ Р 52379-2005 ничего не будет, он как существовал, так и продолжит свое существование.

ГОСТ - это национальный стандарт. Согласно закону

«О техническом регулировании» стандарт - это документ для добровольного многократного использования. Строго говоря, он не является нормативным правовым актом государства в прямом смысле этого слова. Однако его наличие дает нам возможность утверждать, что в России применяются правила, аналогичные ICH GCP (поскольку сама Россия не входит в $\mathrm{ICH}$ ). 


\section{Каково практическое значение Приказа № 200н?}

Приказ № 200н наряду с законом «Об обращении лекарственных средств» должен стать основным документом, соблюдение норм которого будет проверять Росздравнадзор (как орган, уполномоченный на осуществление контроля в сфере клинических исследований) при проведении проверок деятельности участников рынка.

Кроме того, в качестве требований локального законодательства, Приказ № $200 \mathrm{H}$, скорее всего, будет представлять определенный интерес для аудиторов. 


\section{Каково практическое значение Приказа № 200н?}

Поскольку с 4 сентября 2016 г. Приказ Минздрава России от 19.06.2003 № 266 утрачивает силу, а новые Правила применяются к исследованиям, заявления о выдаче разрешений на проведение которых поданы после вступления Приказа № 200н в силу, Росздравнадзор с 4 сентября 2016 г. при проведении проверок текущих исследований, заявления на проведение которых поданы до 4 сентября 2016 г., не сможет в своих замечаниях ссылаться на Правила.

Единственной правовой основой для порядка проведения подобных исследований с точки зрения контролирующего органа будет закон «Об обращении лекарственных средств» 


\section{На что еще сmоum обратить внимание?}

Напоминаем, что одним из требований по аккредитации медицинских организаций на право проведения клинических исследований, согласно Правилам аккредитации, утвержденным постановлением Правительства от 03.09.2010 № 683, является «наличие копий нормативных правовых актов, регламентирующих вопросы организации и проведения клинических исследований лекарственных препаратов для медицинского применения» ${ }^{1}$.

Таким образом, начиная с 0 часов 4 сентября 2016 г. все медицинские организации, аккредитованные на право проведения клинических исследований, должны изъять из соответствующего файла копию Приказа Минздрава России от 19.06.2003 № 266 и заменить ее копией Приказа Минздрава России от 01.04.2016 № 200н.

1Для тех, кто впервые услышал об этом требовании, поясняем: копии нормативных правовых актов должны находиться в центре, их не надо предоставлять в Минздрав России при прохождении процедуры аккредитации, продления аккредитации и пр. 